\title{
STRATEGI OPTIMALISASI PERAN PENDIDIKAN SEKS USIA DINI DI PAUD DALAM MENANGGULANGI PELECEHAN SEKS TERHADAP ANAK DI PEKALONGAN
}

\author{
Dwi Ario Fajar, S.S., M.Hum., Susanto, S.S., M.Hum., Ribut Achwandi S.S.
}

\begin{abstract}
ABSTRAK
Pelecehan seks terhadap anak merupakan salah satu ancaman bagi bangsa yang dapat merusak anak-anak, baik secara fisik, pola pikir, mental, maupun kejiwaan mereka. Pelecehan seks terhadap anak tidak hanya dianggap sebagai tindak kriminal, melainkan pula sudah sepatutnya digolongkan sebagai tindakan perusakan moral. Oleh sebab itu, penanggulangannya harus dilakukan secara menyeluruh dan melibatkan semua komponen bangsa. Penelitian ini berusaha mengungkap strategi di dalam mengoptimalkan peran pendidikan seks usia dini di PAUD dalam menanggulangi pelecehan seks terhadap anak. Melalui pendidikan seks usia dini, kerja sama lintas sektoral yang dilakukan BPMP2KB Kota Pekalongan - melalui LPPAR dan PNFI-dengan penyelenggara PAUD menjadi syarat yang harus dipenuhi. Penelitian ini berupaya mengungkap langkah yang dilakukan oleh pihak-pihak terkait dalam menyelenggarakan pendidikan seks usia dini. Tujuannya, agar didapat langkah-langkah strategis yang dapat dilakukan oleh masing-masing lembaga sebagai masukan.

Penelitian ini melibatkan LPPAR, PNFI, dan 10 lembaga penyelenggara PAUD di Kecamatan Pekalongan Utara sebagai responden. LPPAR dan PNFI merupakan lembaga yang bertanggung jawab menangani masalah kekerasan seks terhadap anak dan penyelenggaraan pendidikan non formal dan informal. Sementara, kecamatan Pekalongan Utara merupakan kawasan yang paling rawan terhadap kasus pelecehan seks terhadap anak di Pekalongan. Dari hasil kuesioner dan wawancara, didapat bahwa upaya yang dilakukan oleh semua pihak di dalam menyelenggarakan pendidikan seks usia dini di PAUD masih menemui beberapa kendala. Kendala utamanya adalah lemahnya koordinasi lintas lembaga, sehingga upaya-upaya yang dilakukan tidak terencana dengan baik. Selain itu, belum terlaksananya revitalisasi kurikulum dan penyediaan perangkat pembelajaran juga menjadi kendala. Oleh sebab itu, kerja sama antarlembaga perlu ditingkatkan.
\end{abstract}

Kata kunci: Pendidikan Seks Usia Dini, PAUD, PNFI, BPMP2KB

\section{PENDAHULUAN}

\subsection{Latar Belakang}

$$
\text { Upaya menanggulangi }
$$
pelecehan seksual terhadap anak, menjadi masalah yang diseriusi oleh pemerintah. Melalui penerbitan Inpres nomor 5 tahun 2014 tentang GN-AKSA (Gerakan Nasional Anti Kekerasan Seksual terhadap Anak), 1 pemerintah berupaya mengerahkan semua komponen, baik lembaga pemerintah maupun masyarakat untuk ikut terlibat dalam memberantas kekerasan seksual terhadap anak. Komitmen semacam ini tentunya membutuhkan langkahlangkah yang implementatif dan aplikatif yang menyentuh ke segala lapisan masyarakat. Salah satu bidang yang mampu menyentuh pada semua lapisan masyarakat adalah pendidikan. Melalui pendidikan, upaya pemberantasan kekerasan seksual terhadap anak dapat dilakukan secara menyeluruh, sebab pendidikan memiliki fungsi sebagai alat penyadaran. Tetapi, pada kenyataannya, dunia pendidikan tidak jarang pula justru tersandera oleh perilaku menyimpang. Kekerasan seksual terhadap anak 
bahkan merebak di lembaga-lembaga pendidikan. Terakhir, kasus JIS mendapatkan sorotan tajam dari media massa. Kasus ini telah memancing emosi masyarakat, sehingga masyarakat merasa geram dan hampir kehilangan kepercayaan terhadap institusi pendidikan. Hal tersebut tentu sangat memrihatinkan. Mengingat lembaga pendidikan yang menjadi salah satu agen moral, justru direcoki oleh kejadian yang sama sekali immoral. Bahkan menurut data yang terhimpun oleh Komisi Perlindungan Anak Indonesia (KPAI), 46\% kasus pelecehan seksual terhadap anak justru terjadi di lingkungan sekolah yang melibatkan guru dan murid sebagai pelaku. Salah satu faktor penyebab terjadinya kasus-kasus tersebut adalah minimnya informasi yang diterima oleh masyarakat tentang gejala-gejala yang mengarah pada tindak pelecehan seksual terhadap anak, bentuk tindakan, dan batasan-batasannya. Pada umumnya, pelecehan seksual dipahami sebatas pada tindakan pencabulan atau perkosaan. Oleh sebab itu, fungsi pendidikan sebagai alat penyadaran mestinya dapat memberikan informasi yang lebih lengkap dan tepat. Pendidikan mestinya mampu menjadi katarsis dari kesimpangsiuran informasi, sehingga memberikan jaminan kepada masyarakat di dalam mendapatkan informasi yang benar. Dalam pada itu, pendidikan seks sudah sepatutnya mendapat perhatian. Pendidikan seks menjadi sangat perlu diberikan kepada masyarakat sebagai langkah preventif sekaligus kontrol sosial terhadap gejala-gejala penyimpangan seksual, khususnya pelecehan seks terhadap anak.

Menurut Ulwan (1995:595), ruang lingkup pendidikan seks tidak hanya mengajarkan mengenai seksualitas, tetapi juga berhubungan dengan aspek moral, etika, hukum, budaya, dan perilaku sosial. Oleh sebab itu, pendidikan seks, seperti ditegaskan Sarwono (2004:118), dapat digunakan sebagai cara untuk mengurangi atau mencegah penyalahgunaan seks, khususnya untuk mencegah dampak- dampak negatif yang tidak diharapkan seperti kehamilan yang tidak direncanakan, penyakit menular seksual, depresi dan perasaan berdosa. Oleh karena itu, tidak berlebihan jika Dr. Rose Mini AP, M.Psi menyatakan bahwa pengetahuan mengenai seksualitas bagi anak wajib diberikan orangtua sedini mungkin, terutama saat anak masuk play group (usia 3-4 tahun). Tujuannya, agar mereka mengenal persamaan dan perbedaan antara pribadi seorang anak laki-laki dan perempuan, sehingga anak mampu mengenali diri mereka dengan baik. Untuk merealisasikan pelaksanaan pendidikan seks usia dini dibutuhkan keterlibatan semua pihak. Melalui kewenangannya, pemerintah perlu mendorong masyarakat untuk terlibat dalam mendukung pelaksanaan pendidikan seks usia dini sebagai langkah preventif pelecehan seksual terhadap anak. Langkah itu dirasa efektif karena dapat mengoptimalkan fungsi lembaga pendidikan sebagai kontrol sosial yang ikut bertanggung jawab atas permasalahan etika, susila, perilaku sosial, dan moral. Diharapkan pula langkah itu akan 
dapat menciptakan hubungan yang simbiosis mutualis antara lembagalembaga yang berwenang — seperti BPMP2KB, Dinas Pendidikan Pemuda dan Olahraga, dan pengelola sekolah-dengan masyarakat. Atas dasar itu, penelitian ini berusaha memberikan gambaran tentang pelaksanaan pendidikan seksual usia dini baik di tingkat pemangku kepentingan seperti PNFI dan BPMP2KB sampai tindak lanjut berupa pelaksanaan pendidikan seksual usia dini di sekolah Pendidikan Anak Usia Dini. Selain itu, setelah diketahui gambaran pelaksanaan pendidikan seksual usia dini ini kemudian dianalisis kembali dengan menggunakan analisis SWOT untuk menghasilkan strategistrategi dalam usaha untuk mengoptimalkan pelaksanaan pendidikan seksual anak usia dini.

\subsection{Rumusan Masalah}

Masalah di dalam penelitian ini meliputi:

1. Bagaimana peran PNFI dan Bapermas dalam menyikapi fenomena pelecehan seks usia dini?

2. Bagaimana peran kepala sekolah dalam Pendidikan Seks Usia Dini?

3. Bagaimana peran guru dalam menindaklanjuti Pendidikan Seks Usia Dini dalam pembelajaran?

4. Bagaimana strategi untuk untuk mengoptimalkan Pendidikan Seks Usia Dini di Pekalongan?

\subsection{Tujuan Penelitian}

Penelitian ini bertujuan memberikan dukungan sekaligus dorongan kepada pihak-pihak terkait pengelola lembaga pendidikan anak usia dini, baik kepala sekolah maupun guru, dalam menindaklanjuti fenomena pelecehan seksual anak dalam pembelajaran peserta didik.

\subsection{Kontribusi Penelitian}

Kontribusi yang diharapkan dalam penelitian ini adalah adanya evaluasi pelaksanaan pengajaran Pendidikan Seks Usia Dini di PAUD guna mengantisipasi fenomena pelecehan seksual anak. Diharapkan pula, hasil penelitian ini dapat dijadikan rujukan bagi Pemerintah kota Pekalongan guna membuat kebijakan yang lebih baik berkenaan dengan upaya pemberantasan tindak pelecehan seks anak di Pekalongan.

\section{KAJIAN TEORI}

2.1 Perkembangan Seksualitas pada Anak Usia Dini

Perkembangan psikoseksual, menurut Freud (Hurlock, 2001), dimulai sejak anak dilahirkan. Dalam hal ini, Freud membagi tahap-tahap perkembangan tersebut ke dalam empat tahap, yaitu: (1) fase oral (0-2 tahun), (2) fase muskuler (2-3 tahun), (3) fase anal uretral (3-5 tahun), dan (4) fase genital (5-7 tahun). Meski demikian, pengalaman seksualitas pada anak usia dini tidak sama dengan pengalaman orang dewasa. Hastomo (2007) mengungkapkan bahwa secara umum pengalaman seksualitas pada anak usia dini lebih menekankan pada perilaku atau kebiasaan. Sedangkan fungsi seksualnya belum 
mengalami perkembangan yang signifikan. Hal ini disebabkan hormon-hormon pada anak belum berfungsi secara maksimal. Hasil penelitian yang dilakukan Kinsey Institute menyebutkan bahwa ketika dilahirkan semua bayi yang normal akan mengalami perubahan hormonal. Pasokan hormon testosteron dan estrogen akan menurun secara drastis dalam waktu satu atau dua hari. Pada bayi lakilaki hormon testosteron akan meningkat dalam waktu sebulan kemudian. Selama itu pula pasokan hormon tetap tinggi. Setelah itu, secara berangsur pasokan hormon akan menurun hingga tingkat terendah. Keadaan itu akan terus berlangsung sampai anak-anak mengalami perubahan hormonal lagi semasa pubertas dimulai, yaitu antara usia 8-12 tahun (Master dkk dalam Raharjo, 2009:5). Seiring dengan perkembangan tersebut, anak perlu mendapatkan informasi yang benar megenai seksualitas. Pemenuhan atas rasa keingintahuan anak-anak (terutama dimulai sejak usia tiga tahun) akan melibatkan berbagai eksplorasi yang dilakukannya, baik pada dirinya dan orang lain. Di sinilah peran pendidikan seks menjadi penting bagi anak, orangtua, dan lingkungan terdekat mereka.

\subsection{Pendidikan Seks}

Merujuk pada pemikiran Ulwan (1995:595), pendidikan seks tidak semata mengajarkan atau memberi pengetahuan mengenai seksualitas, melainkan pula berhubungan dengan aspek moral, etika, hukum, budaya, dan perilaku sosial. Menurutnya, pendidikan seks merupakan sebuah upaya pengajaran, penyadaran, dan penerangan tentang masalah-masalah yang berkenaan dengan naluri seks dan perkawinan. Tujuannya, agar anak dapat memahami urusan-urusan kehidupan, mengetahui masalahmasalah yang diharamkan dan dihalalkan, menerapkan tingkah laku yang sesuai dengan tuntunan agama dan kebiasaan hidup, serta mampu mengendalikan hawa nafsu seksual dan menghindari periaku hedon. Oleh sebab itu, menurut Sarwono (2004:118), pendidikan seks dapat digunakan sebagai suatu cara untuk mengurangi atau mencegah penyalahgunaan seks, khususnya mencegah dampak-dampak negatif yang tidak diharapkan seperti kehamilan yang tidak direncanakan, penyakit menular seksual, depresi dan perasaan berdosa. Dengan kata lain, pendidikan seks merupakan bagian penting dalam mendidik anak dan bukan perihal yang harus dipandang tabu. Hal senada juga diungkapkan Sulistyo (dalam Tanjung, 2007:217) bahwa tujuan pendidikan seks adalah menghasilkan manusia-manusia dewasa yang dapat menjalankan kehidupan dengan bahagia karena dapat menyesuaikan diri dengan masyarakat dan lingkungannya, serta bertanggung jawab terhadap dirinya dan orang lain. Oleh sebab itu, Bruess dan Cassidy (dalam Qibtiyah, 2006:5) menekankan pentingnya pendidikan seks di dalam menyediakan kebutuhan informasi yang benar dan luas tentang perilaku seksual guna memahami seksualitas manusia sebagai bagian penting dari 
kepribadian yang menyeluruh.

\subsection{Pendidikan Seks Usia Dini}

Menurut Dr. Rose Mini AP, M.Psi, pengetahuan mengenai seksualitas bagi anak wajib diberikan orangtua sedini mungkin, saat anak masuk play group (usia 3-4 tahun). Anak-anak perlu diajarkan tentang persamaan dan perbedaan antara pribadi seorang anak laki-laki dan perempuan. Tujuannya, agar anak mampu mengenali diri mereka dengan baik. Meski demikian, pendidikan seks diberikan dengan menyesuaikan kesiapan psikologi anak. Salah satu cara penyampaian yang dapat dilakukan dalam mengajarkan pendidikan seks usia dini dimulai dari mengajari dan membiasakan anak agar membersihkan alat kelaminnya sendiri setelah buang air kecil maupun buang air besar. Tujuannya, agar anak mandiri dan tidak bergantung pada orang lain. Penanamaan sikap mandiri akan memberikan pengajaran pada anak tentang etika. Dengan demikian, pendidikan seks pada anak usia dini mampu diterapkan sebagai upaya pencegahan agar terhindar dari pelecehan seksual.

\subsection{Kekerasan Seksual}

Poerwandari

mendefinisikan kekerasan seksual sebagai tindakan yang mengarah pada ajakan/desakan seksual seperti menyentuh, meraba, mencium, dan atau melakukan tindakan-tindakan lain yang tidak dikehendaki oleh korban, memaksa korban menonton produk pornografi, gurauan-gurauan seksual, ucapan-ucapan yang merendahkan dan melecehkan dengan mengarah pada aspek jenis kelamin/seks korban, memaksa berhubungan seks tanpa persetujuan korban dengan kekerasan fisik maupun tidak; memaksa melakukan aktivitas-aktivitas seksual yang tidak disukai, merendahkan, menyakiti atau melukai korban. Dengan demikian, tindak kekerasan seksual meliputi tiga aspek, yaitu ucapan, perbuatan dan visualisasi. Sisca dan Moningka (2009) mengatakan bahwa kekerasan seksual yang terjadi pada masa kanak-kanak merupakan peristiwa krusial karena berdampaknegatif pada kehidupan korban di masa dewasanya. Sedang Mboiek (1992) dan Stanko (1996) mendefinisikan kekerasan seksual adalah suatu perbuatan yang biasanya dilakukan laki-laki dan ditujukan kepada perempuan dalam bidang seksual yang tidak disukai oleh perempuan sebab ia merasa terhina, tetapi kalau perbuatan itu ditolak ada kemungkinan ia menerima akibat buruk lainnya. Suhandjati (2004) mengatakan bahwa seseorang dikatakan sebagai korban kekerasan apabila menderita kerugian fisik, mengalami luka atau kekerasan psikologis, trauma emosional, tidak hanya dipandang dari aspek legal, tetapi juga sosial dan kultural. Bersamaan dengan berbagai penderitaan itu, dapat juga terjadi kerugian harta benda. The nation center on child abuse and neglect 1985, (Tower, 2002) menyebutkan beberapa jenis kekerasan seksual berdasarkan pelakunya, yaitu: 1. Kekerasan yang dilakukan oleh anggota keluarga. 2. Kekerasan yang dilakukan oleh 
orang lain di luar anggota keluarga.

\section{Metode Penelitian}

\subsection{Lokasi Penelitian}

Penelitian ini dilaksanakan di wilayah kota Pekalongan, khususnya di kecamatan Pekalongan Utara, selama 6 bulan. Sedangkan objek peneltian meliputi sekolah PAUD di wilayah Kecamatan Pekalongan Utara.

3.2 Metode Penelitian

Penelitian ini merupakan
penelitian evaluasi pendidikan. Sebagai penelitian evaluasi, maka di dalam penelitian ini aspek yang dianalisis meliputi aspek input, proses dan output. Metode yang digunakan dalam penelitian ini adalah metode deskriptif kualitatif. Sementara, teknik yang dipergunakan dalam penelitian ini adalah dengan sarana angket (kuesioner) dan wawancara langsung. Sedangkan data yang digunakan dalam penelitian ini berasal dari dua macam sumber data. Data primer dalam penelitian ini diperoleh dari observasi melaui wawancara, penyebaran kuesioner kepada PNFI, Bapermas, kepala sekolah dan guru PAUD. Sedangkan data sekunderdiperoleh dari peraturan perundang-undangan dan hasil-hasil karya ilmiah para sarjana yang berkaitan dengan permasalahan yang sedang diteliti.

\subsection{Teknik Penarikan Sampel}

Teknik penarikan sampel yang digunakan adalah dengan metode Purposive Sampling. Metode ini dilakukan dengan cara mengambil objek penelitian yang didasarkan pada suatu tujuan tertentu. Dalam penelitian ini, objek penelitian adalah PNFI dan BPMP2KB serta PAUD di kecamatan Pekalongan Utara dengan responden penelitian ini adalah Kepala sekolah dan guru. Dipilihnya PNFI,karena kewenangannya dalam menindaklanjuti fenomenafenomena pelecehan seksual anak. Dalam hal ini, PNFI bertanggung jawab atas pelaksanaan kebijakankebijakan yang berkaitan dengan pendidikan usia dini. Sedang, pemilihan BPMP2KB dikarenakan oleh tugas dan tanggung jawabnya dalam upaya penyebarluasan dan sosialisasi pendidikan seks bagi anak. Penelitian ini diarahkan pada pelaksanaan pendidikan seks di sekolah- sekolah PAUD di wilayah Kecamatan Pekalongan Utara. Kecamatan Pekalongan Utara merupakan kawasan dengan tingkat kerawanan kasus pelecehan seksual terhadap anak tertinggi di Pekalongan. Hal ini berkaitan pula dengan kondisi sosio kultur masyarakat yang tergolong sebagai masyarakat pesisir. Adapun jumlah sampel yang diambil sebanyak 10 PAUD dari 10 kelurahan di kecamatan Pekalongan Utara.

Untuk mendapatkan informasi, penelitian ini menggunakan instrumen kuesioner dan wawancara. Kuesioner bertujuan untuk mendapatkan informasi awal sedangkan wawancara dipakai untuk menggali informasi lebih dalam.

\section{Analisis Data dan Pembahasan}




\subsection{Analisis Data}

Bagian ini menyajikan data yang diperoleh dari lapangan melalui kuesioner dan wawancara. Kuesioner dan wawancara dilakukan terhadap kepala sekolah dan guru PAUD di 10 kelurahan di Kecamatan Pekalongan Utara yaitu Kelurahan Pabean, Panjang Baru, Kandang Panjang, Panjang Wetan, Dukuh, Bandengan, Degayu, Kraton, Krapyak Lor dan Krapyak Kidul.

\subsubsection{BPMP2KB}

Kuesioner dan wawancara yang dilakukan dengan kepala LPPAR, Nur Agustina, M.Psi menunjukkan bahwa dalam kurun waktu tiga tahun terakhir kasus kekerasan seksual terhadap anak di empat kecamatan terus bertambah. Tahun 2012, kasus pelecehan seksual terhadap anak di kecamatan Pekalongan Barat dan Timur tercatat 4 kasus. Jumlah kasus itu naik menjadi 5 kasus pada tahun 2013. Sementara, di Pekalongan Selatan, pada tahun 2012 terdapat 1 kasus dan 2 kasus 2013. Sedang, di Pekalongan Utara, pada tahun 2012 terdapat 6 kasus dan meningkat dua kali lipat menjadi 12 kasus di tahun 2013. Sementara pada tahun 2014, jumlah kasus yang terjadi sampai bulan Juli kasus kekerasan seksual terhadap anak telah menyamai jumlah kasus tahun 2013. Tindak lanjut yang dilakukan LPPAR adalah dengan sosialisasi tentang pentingnya pendidikan seksual usia dini. Sosialisasi dilakukan di Pekalongan Utara dengan sasaran para guru. Sosialisasi juga dilakukan sebagai respon terhadap pemberitaan mengenai maraknya kasus pelecehan seksual terhadap anak,seperti kasus JIS (Jakarta International School) dan kasus Emon.Tetapi, sosialisasi belum mampu menjangkau guruguru PAUD, sebab sosialisasi hanya diberikan kepada sekolah yang memiliki TK. Sedangkan untuk PAUD atau SPS

yang tidak mempunyai TK belum mendapatkan sosialisasi. Tercatat, dari PAUD responden, hanya guru dan kepala sekolah PAUD di kelurahan Kraton Lor yang mendapatkan sosialisasi karena institusi ini memiliki TK. Meskipun sosialisasi telah dilaksanakan, pelaksanaan pendidikan seks usia dini belum dapat direalisasikan. Hal ini disebabkan oleh belum terselenggaranya pelatihan yang intensif bagi kepala sekolah dan guru dan belum tersedianya petunjuk teknis, seperti perangkat pembelajaran dan evaluasi pembelajaran.

\subsubsection{PNFI/ PAUDNI}

Dari hasil kuesioner dan wawancara yang dilakukan dengan Kepala Bidang Pendidikan Non Formal dan Informal (Kabid PNFI) Drs. Ahmad Saumu, didapat bahwa berdasarkan pemetaan daerah-dearah rawan pelecehan seks terhadap anak, PNFI merumuskan upaya penanggulangan pelecehan seks terhadap anak dengan melaksanakan pendidikan seksual usia dini yang dilakukan di PAUD.Rumusan itu ditindaklanjuti melalui sosialisasi dan pelatihan kepada kepala sekolah PAUD. Namun, sosialisasi tersebut belum optimal. Sosialisasi hanya menekankan pada upaya 
menciptakan pendidikan tanpa kekerasan. Topik ini masih terlalu luas cakupannya dan tidak spesifik membahas pendidikan seks usia dini. Kurang optimalnya upaya yang dilakukan PNFI juga ditunjukkan melalui belum terlaksananya revitalisasi kurikulum untuk PAUD. Akibatnya, pelaksanaan pendidikan seks usia dini di PAUD terkendala karena guru dan kepala sekolah belum memiliki pedoman yang berupa petunjuk teknis, perangkat pembelajaran, maupun evaluasi keberhasilan pelaksanaan pendidikan seks usia dini. Meski demikian, Kepala PNFI kota Pekalongan mengaku bahwa sosialisasi yang dilakukan tidak bersifat terbatas. Pihaknya menggandeng Pemerintah kota Pekalongan dalam pencanangan pemberantasan pelecehan seks usia dini dengan sasaran kegiatan masyarakat secara umum. Sosialisasi ini diklaim sebagai cara efektif untuk memotivasi masyarakat agar lebih peduli dan waspada terhadap ancaman pelecehan seks terhadap anak.

\subsubsection{Kepala Sekolah}

Berdasarkan hasil kuesioner dan wawancara yang dilakukan dengan kepala sekolah PAUD ditemukan bahwa sosialisasi pendidikan seks usia dini belum merata. Menurut sejumlah kepala sekolah PAUD, sosialisasi yang dilakukan PNFI tidak tepat sasaran, karena tidak membahas masalah pendidikan seks usia dini, melainkan lebih terfokus pada pendidikan tanpa kekerasan. Kendati demikian, sosialisasi tersebut tetap ditindaklanjuti oleh kepala sekolah PAUD kepada orangtua murid. Tetapi, sosialisasi tidak dapat dilaksanakan kepada masyarakat secara sistematis, mengingat keterbatasan yang dimiliki PAUD.

\subsubsection{Guru}

Dari hasil kuisioner dan wawancara yang dilakukan didapatkan bahwa pelaksanaan pendidikan seks usia dini telah dilakukan guru, tetapi belum dilaksanakan secara sistematis. Guru hanya mengandalkan pengalaman mereka tanpa dibekali perangkat pendidikan seksual usia dini yang memadai, sehingga evaluasi pembelajaran yang sistematis tentang pendidikan seksual usia dini belum dapat dilaksanakan. Selain itu, guru juga belum diberikan alat ukur keberhasilan pendidikan seksual usia dini.

\subsubsection{Orangtua}

Melalui hasil kuesioner dan wawancara dengan sejumlah orangtua murid, didapat bahwa orangtua murid masih menganggap seks sebagai perihal yang tabu bagi anak-anak. Orangtua beranggapan bahwa membicarakan seks sebagai hal yang tidak etis. Oleh sebab itu, pendidikan seks tidak perlu diberikan kepada anak usia dini karena akan bertentangan dengan norma-norma dan budaya masyarakat. Para orangtua mengaku bahwa mereka merasa tidak nyaman ketika harus mengajarkan tentang seks bagi anak-anak mereka. Mereka merasa tidak memiliki kemampuan yang memadai untuk mengajarkan anak-anak mereka tentang 
pendidikan seks. Bahkan, mereka cenderung enggan untuk mendidik anak-anak mereka, terutama hal-hal yang berkaitan dengan pengajaran di sekolah. Menurut mereka, dunia pengajaran adalah tanggung jawab pihak sekolah. Oleh sebab itu, proses pembelajaran anak hanya berlaku di sekolah. Sementara di rumah, anak- anak cenderung dibiarkan untuk bermain. Kendati demikian, para orangtua mengaku bahwa mereka tidak akan membiarkan anak-anak mereka terlibat masalah. Tetapi, cara mereka cenderung menyalahkan pihak lain ketika anak mereka terlibat masalah. Orangtua akan meminta pertanggungjawaban pada sekolah atau kepada orangtua murid lainnya yang bermasalah. Mereka beranggapan bahwa ketika anak di sekolah, guru dan kepala sekolah harus memberi pengawasan terhadap anak-anak.

\subsection{Pembahasan}

Analisis data yang dipaparkan sebelumnya mengungkap bahwa realisasi Pendidikan Seks Usia Dini di PAUD masih dijalankan secara parsial. BPMP2KB Kota Pekalongan-melalui LPPAR dan PNFI-belum mampu menjalankan fungsinya secara maksimal. Bahkan, terjadi tumpang tindih kewenangan yang justru menunjukkan lemahnya koordinasi dan kelemahan dalam perencanaan program kerja dan kegiatan yang dilakukan oleh masing-masing lembaga.Padahal, Inpres nomor 5 tahun 2014 mengamanatkan agarpenanggulangan ancaman pelecehan seksual terhadap anak dilaksanakan secara berjenjang, terkoordinir, tersistem, terintegrasi, serta melibatkan seluruh unsur masyarakat dan dunia usaha. Lemahnya koordinasi ini terlihat lewat perbedaan persepsi yang ditunjukkan antara LPPAR dan PNFI. LPPAR lebih responsif dalam menyikapi setiap perkembangan isu, sehingga sosialisasi yang dilaksanakan mampu membidik topik-topik yang menjadi isu terkini. Sementara, PNFI kurang dapat menunjukkan kesiapan dan sikap responsif terhadap perkembangan isu. Kendati demikian, LPPAR memiliki kewenangan yang terbatas. Kapasitas LPPAR sebatas pada upaya memberikan sosialisasi yang bersifat umum, bukan pada persoalan yang lebih teknis atau spesifik pada bidang-bidang tertentu. Oleh sebab itu, sosialisasi tidak dikhususkan pada upaya pelaksanaan pendidikan seks usia dini.Hal ini semestinya ditindaklanjuti oleh PNFI melalui sosialisasi yang khusustentang penyelenggaraan pendidikan seks usia dini. Tetapi, sosialisasi yang dilakukan PNFI justru terkesan seremonial. Pencanangan gerakan pemberantasan pelecehan seksual terhadap anak justru kurang mengena sasaran karena tidak fokus dan terlalu luas cakupannya, sehingga capaian keberhasilannya pun tidak dapat diukur. Sementara, sosialisasi pendidikan seks usia dini yang menjadi kewenangan PNFI justru kurang mendapat perhatian. Pelatihan bagi kepala sekolah belum secara khusus mengarahkan pada realisasi pendidikan seks usia dini, melainkanhanya mengetengahkan topik yang masih bersifat umum, 
terutamamenyangkut metode dan strategi pembelajaran. Hal ini diperparah dengan belum terlaksananya revitalisasi kurikulum untuk PAUD. Seperti diketahui, kurikulum pada pendidikan non formal dan informal cenderung bersifat terbuka, sehingga dapat direvitalisasi sewaktu-waktu dengan menyesuaikan kebutuhan. Sementara, pihak sekolah menganggap bahwa upaya yang dilakukan PNFI masih belum dapat dirasakan ke seluruh pengelola PAUD. Sosialisasi tentang pendidikan seks usia dini tidak dilakukan secara merata ke seluruh sekolah. Selain itu, tindak lanjut dari sosialisasi pun belum ada. Hal ini menunjukkan bahwa fungsi pembinaan dan pengawasan PNFI terhadap penyelenggara PAUD masih lemah. Kondisi tersebut diperkuat dengan belum tersedianya petunjuk teknis dan perangkat pembelajaran bagi sekolah guna menyelenggarakan pendidikan seks usia dini. Meski demikian, sejumlah kepala sekolah menyatakan bahwa pihaknya sudah berinisiatif menyelenggarakan pendidikan seks usia dini. Hanya saja belum tersistem dengan baik. Pola pengajaran hanya berdasarkan pengalaman para guru. Hal ini memperlihatkan bahwa secara kelembagaan, pihak sekolah sebenarnya lebih siap dibandingkan dengan PNFI.

Di lain pihak, sejumlah guru pengajar PAUD mengaku, secara otodidak, telah melaksanakan pendidikan seks usia dini. Tetapi, pengajaran pendidikan seks usia dini belum dilakukan secara sistematis.
Para guru menganggap bahwa penerimaan orangtua murid sangat baik terhadap pendidikan seks usia dini, sebab penyampaian materi lebih diarahkan pada upaya pemahaman dan penghayatan ajaran-ajaran agama, khususnya berkenaan dengan adab dan akhlak. Namun, keterukuran tingkat keberhasilan pembelajaran belum dapat dipenuhi, karena petunjuk teknis dan evaluasi belum ada. Kendati demikian, sejumlah guru beranggapan bahwa pendidikan seks usia dini merupakan hal baru. Oleh karena itu, mereka sangat berharap PNFI memberikan pelatihan kepada guru, karena ujung tombak dari pelaksanaan pendidikan seks usia dini adalah guru.

Jika demikian, koordinasi lintas lembaga masih sangat lemah. Di satu sisi, PNFI sebagai lembaga yang memayungi penyelenggaraan PAUD kurang sigap menjalankan tugas dan fungsinya. Di sisi lain, muncul pula sikap enggan dari pengelola sekolah PAUD untuk memberikan kritik, saran, dan masukan kepada lembaga-lembaga payung mereka. Pengelola sekolah PAUD dan tenaga pengajar di PAUD cenderung pasif dan kurang berinisiatif untuk mengajukan usulan kepada lembaga-lembaga terkait. Kendala lain yang dialami sekolah PAUD dalam melaksanakan pendidikan seks usia dini adalah sikap dan perilaku orangtua murid yang belum mengajarkan sikap mandiri pada anak-anak mereka. Kebiasaan orangtua menunggi anakanak mereka di sekolah mengganggu proses pembelajaran karena anak menjadi manja dan sangat 
bergantung pada orangtua. Hal ini memperlihatkan dua kemungkinan. Pertama, berkenaan dengan tingkat kepercayaan orangtua murid terhadap pelaksanaan pengajaran di sekolah yang masih rendah. Kedua, sikap orangtua belum sepenuhnya dapat mendidik anak-anak mereka dengan baik. Padahal, pendidikan tidak semata dilakukan dan dilangsungkan di sekolah, melainkan pula di rumah, dan di lingkungan sekitar. Dengan demikian, tingkat kesadaran dan pengetahuan masyarakat tentang pendidikan masih dapat dikatakan rendah.

\section{PENUTUP}

\subsection{Simpulan}

Berdasarkan

paparan

sebelumnya, dapat disimpulkan bahwa pelaksanaan pendidikan seks usia dini di PAUD masih terkendala oleh kinerja PNFI yang kurang responsif. PNFI kurang mampu memenuhi kebutuhan bagi penyelenggaraan pendidikan seks usia dini secara optimal. Hal ini ditunjukkan melalui sosialisasi yang kurang tepat sasaran, belum terlaksananya revitalisasi kurikulum, dan belum tersedianya perangkat pembelajaran, petunjuk teknis serta evaluasi pembelajaran. Selain itu, sosialisasi yang dilakukan PNFI masih belum merata. Beberapa sekolah yang berada di daerah rawan pelecehan seksual anak bahkan belum mendapatkan sosialisasi. Oleh karena itu, PNFI semestinya mengedepaankan asas pemerataan. Dalam maksud ini, seluruh PAUD mendapatkan kesempatan dan juga pendalaman materi yang sama. Sosialisasi yang dilakukan mestinya justru lebih mampu menyentuh sekolah-sekolah yang berada di daerah rawan pelecehan seksual anak seperti di kelurahan Panjang Baru yang kebanyakan penduduknya berasal dari eks pelacuran Boyongsari.

\subsection{Saran}

Mendasarkan pada uraian tersebut, dapat diungkap bahwa untuk mengoptimalkan peranan PAUD dalam melaksanakan pendidikan usia dini ibutuhkan langkah-langkah sebagai berikut:

1. BPMP2KB perlu menata ulang sistem kerja lembaga-lembaga yang ada di bawahnya, khususnya LPPAR dan PNFI, guna menghindari tumpang tindih kewenangan dan membangun sistem koordinasi yang lebih baik.

2. PNFI perlu bersikap lebih tanggap terhadap isu yang berkembang di masyarakat serta mendorong agar pengelola PAUD lebih aktif memberikan masukan dan usulan tentang kebutuhan mereka.

3. PNFI perlu segera merevitalisasi kurikulum dengan mempertimbangkan aspek kondisi riil PAUD di Pekalongan, terutama ketersediaan sarana prasarana dan daya dukung PAUD, serta kondisi sosio kultur masyarakat.

4. Pelatihan yang dilakukan PNFI perlu ditingkatkan. Dalam hal ini, pelatihan tidak hanya diberikan kepada kepala sekolah, tetapi juga harus mampu menjangkau guruguru PAUD. 
5. PNFI perlu melakukan kerja sama lintas sektoral guna mendapatkan masukan dan saran yang dapat dijadikan bahan pertimbangan.

6. Penyelenggara PAUD harus lebih proaktif dalam menyikapi setiap perkembangan yang terjadi di masyarakat, utamanya yang berkenaan dengan isu seputar pelecehan seksual terhadap anak.

7. Penyelenggara PAUD harus memiliki inisiatif $u$ ntuk memberikan masukan dan saran kepada PNFI terkait penyelenggaraan pendidikan usia dini di PAUD.

8. Penyelenggara PAUD perlu lebih kreatif di dalam merancang strategi pembelajaran pendidikan seks usia dini meskipun ketersediaan sumber daya manusia dan sarana prasarana masih sangat terbatas.

9. Penyelenggara PAUD perlu meningkatkan kompetensi guru dengan menyelenggarakan atau mengikutsertakan guru dalam kegiatan pelatihan yang sesuai dengan kebutuhan.

10.Penyelenggara PAUD perlu memberikan masukan kepada PNFI tentang kebutuhankebutuhan mereka, sehingga tindak lanjut yang dilakukan PNFI dapat dilaksanakan sesuai dengan kebutuhan mereka.

\section{DAFTAR PUSTAKA}

Arivia, G. (2003). Filsafat berspektif feminis.

Yayasan Jurnal Perempuan. Jakarta

Hastomo, Agung. 2007. Pendidikan Seks
Anak (Pendekatan Praktis Bentuk dan Antisipasi Penyimpangan Seks Anak). (Makalah). Disampaikan pada Seminar Pengembangan Ilmu Pendidikan, di Fakultas Ilmu Pendidikan, Universitas Negeri Yogyakarta, 3 Maret 2007.

Kania, Nia, dr., SpA, M.Kes. 2007. "Stimulasi Dini untuk Mengembangkan Kecerdasan dan Kreativitas Anak" (Makalah). Disampaikan pada acara Talkshow Stimulasi Tumbuh Kembang Anak Sejak Dini di Bandung, 5 Agustus 2007.

Mboiek, Pieter B., "Pelecehan Seksual Suatu Bahasan Psikologis Paeda-gogis," makalah dalam Seminar Sexual Harassment, Surakarta 24 Juli (Surakarta : Kerjasama Pusat Studi Wanita Universitas Negeri Surakarta dan United States Information Service, 1992).

Poerwandari, E. K. (2000). Kekerasan terhadap perempuan: tinjauan psikologi feministik, dalam Sudiarti Luhulima (ed) "Pemahaman Bentukbentuk tindak kekerasan terhadap perempuan dan alternative pemecahannya”, Jakarta: Kelompok kerja "convention watch" Pusat Kajian Wanita dan Jender, Universitas 
Indonesia.

Qibtiyah, Alimatul. 2006. Paradigma Pendidikan Seksualitas. Penerbit Kurnia Kalam Semesta.

Sarwono, Sarlito Wirawan. 2004. Psikologi Remaja. Jakarta: Raja Grafindo Persada.

Sisca, H., dan Moningka, C. (2009). Resiliensi perempuan dewasa muda yang pernah mengalami kekerasan seksual di masa kanak-kanak. Jurnal Proceeding PESAT (Psikologi, Ekonomi, Sastra, Arsitektur \& Sipil) Vol : 3 Oktober 2009.

Stanko, Elizabeth A., "Reading Danger: Sexual Harassment, Anticipation and Self -Protection," dalam Marianne Hester (ed.) Women Violence and Male Power: Feminist Activism, Research and Practice (Buckingham: Open University Press,1996).

Suhandjati, S. (2004). Kekerasan terhadap istri. Yogyakarta: Gama Media.

Sulistyaningsih, E., \& Faturochman (2002). Dampak sosial psikologis perkosaan. Buletin Psikologi, Tahun X, No. 1, Juni 2002, 9-23. Yogyakarta: Universitas Gadjah Mada.

Tower, C. (2002). Understanding Child
Abuse and Neglect (5th ed). Boston: Allyn dan Bacon, A Pearson Education Company. 17

Ulwan, Abdullah Nashih. 1995. Pendidikan Anak dalam Islam (di indonesiakan oleh Jamaludin Miri). Jakarta: Pustaka Amani. 